Article

\title{
Genius and Genitality: William S. Burroughs Reading Wilhelm Reich
}

\author{
Thomas Antonic (D) \\ Department of German Studies (Institut für Germanistik), University of Vienna, A1010 Vienna, Austria; \\ thomas.antonic@univie.ac.at
}

Received: 15 January 2019; Accepted: 16 May 2019; Published: 21 May 2019

Abstract: This article explores the impact of Wilhelm Reich's theories and writings on the works and thinking of William S. Burroughs. Reich's significance for Burroughs' fiction is beyond doubt, as the appearance of Reich's discoveries and inventions, such as orgones and orgone accumulators, in Burroughs' major works demonstrates. Yet to date, no attempt has been made in academia to make all those references to Reich in Burroughs' complete œuvre visible. In order to make the thinking of the Austrian-American psychoanalyst and scientist comprehensible for readers not familiar with Reich, the first section will provide a brief biographical outline. In the subsequent sections, the article will describe how Burroughs and other Beat writers discovered Reich, how and to what extent Burroughs incorporated Reich in his texts throughout his career and what opinions Burroughs expressed about Reich in interviews and letters. For the first time, with a summary as undertaken in this article and by documenting most of the references to Reich in Burroughs' work, the importance of the former to the latter is revealed in a compact form.

Keywords: William S. Burroughs; Wilhelm Reich; beat generation; orgone

\section{Introduction}

At some point, readers familiar with Beat literature have certainly come across the name of Wilhelm Reich or references to one of his discoveries and inventions in books by or about the Beat Generation. Perhaps the most notable reference can be found in On the Road, in which an orgone accumulator-an invention by Reich—stands in the yard of Old Bull Lee, described by Sal Paradise as "mystical outhouse" (Kerouac [1957] 2000, p. 138; this passage does not exist in the "Original Scroll" version of the book, cf. Kerouac 2007, p. 252). And numerous references to Reich can be found in the works, letters, interviews of William S. Burroughs throughout, from Junky to The Western Lands and beyond. Allan Johnston has written the only scholarly article that analyses Reich's influence on Burroughs but this study is limited to an examination of traces of Reich's theories in Junky and Naked Lunch (Johnston 1984). Apart from a very brief discussion in Michael Stevens' The Road to Interzone (Stevens 2009, pp. 97-98), further examinations do not exist. So, who is the man behind the mystical outhouse, while Old Bull Lee-Kerouac's fictionalization of Burroughs-was sitting in it?

\section{Wilhelm Reich in Vienna in the 1920s and 30s}

Wilhelm Reich was born in 1897 near L'viv, today part of the Ukraine, which back then was within the borders of the Austrian-Hungarian Empire and was known as Lemberg. Following the First World War, he studied medicine in Vienna and soon became a disciple of Sigmund Freud and a member of the inner circle of the Vienna Psychoanalytic Association, as vice director of the Vienna Ambulatorium (Freud's outpatient clinic) between 1924 and 1930. In this clinic, patients that could otherwise not afford to pay for it received free or reduced-cost treatment, many of them shell-shocked from their wartime experiences. 
At that time Reich started developing a theory according to which neuroses, anxieties, depression and other psychic disorders cannot only be rooted in ego defense mechanisms and unconscious conflicts (to outline the concept of psychoanalysis very briefly) but also arise from many irregularities in society, so-called "social evils," undesirable developments in society as a whole: for instance lack of sex education and lack of freedom for people to live out their sexual desires, due to moralistic and political suppression, laws and even due to the bad housing situation. Whereupon a sound sex life is, in short, a basic requirement for a healthy organism (physically and mentally) and subsequently a basic requirement for a functioning society.

Besides his work at Freud's Ambulatorium, Reich himself opened not less than six clinics for people of the lower classes with ambulant sexual problems. These clinics offered medical first aid, psychotherapeutic help and even legal advice by lawyers. In doing so, Reich and his assistants often worked in gray areas of legislation because they, for instance, offered help and gave contraceptives to underage couples and even executed strictly forbidden abortions. "Reich's approach to this issue was amazingly advanced." To him the "essential point was that women should have the right to terminate their pregnancies, regardless of their medical condition or social-economic situation." (Sharaf 1994, p. 134).

The work in both Freud's Ambulatorium and in his own clinics got Reich much more in contact with the working class than Freud. The latter wanted to exclude the aforementioned societal correlations from his psychoanalytic concepts, because he feared that his "pure" science would be endangered, if political elements would get too important for it. But, as the majority of scientists at that time, he missed that in fact no science is really objective and free from ideologies.

This was also Reich's major criticism of Freud, which we find repeated in Burroughs' essay "On Freud and the Unconscious" in The Adding Machine: "Freud, who was one of the early researchers to point out the heavy toll in mental illness exacted by the 19th century's materialistic capitalism, never questioned the underlying ethic. He felt that we have paid a high price for what he calls civilization and the price has been worth it. It did not occur to him to ask if the price was necessary." (Burroughs 1993a, p. 90).

It is no surprise that his theory brought Reich close to the ideas of the Communist movement, which, as he hoped, could accelerate breaking away from familial and societal entanglements, which were responsible for copious occurrences of neurosis. His intentions were not only aimed at healing neurosis through psychoanalysis but also in preventing them by changing society. Moreover, he thought that the communists would support his ideas. As early as in the Communist Manifesto (1848), Marx and Engels had proclaimed the abolishment of the family in favour of free love, the abolishment of the position of women as pure instruments of production and the abolishment of the exploitation of children by their parents in favour of upbringing by society. But we know that this aim was only fulfilled by social realism to a limited degree. And it is a fact that in the 1920s and 30s the Communist Parties in Austria and Germany only supported these causes half-heartedly, as they were afraid of losing prospective voters who were dominated by Christian and other conservative sexual morals. This is actually the reason Wilhelm Reich was expelled from the Communist Party at the beginning of the 1930s.

Additionally, in 1934, Reich was also expelled from the Psychoanalytic Association. Both communists and opponents within psychoanalytic circles started floating rumours such as Reich celebrating orgies in his practice and clinics. Analyst Sandor Rado "diagnosed" an "insidious psychotic process" (Sharaf 1994, p. 194) of Reich, which was spread by psychoanalysts such as Paul Federn, one of Reich's harshest opponents. On top of that Freud considered it as highly problematic, that sexuality was such a strong focus in Reich's work as psychoanalyst. After his publications Beyond the Pleasure Principle (1920) and The Ego and the Id (1923), in which he introduces the concept of the "Death Instinct," his own "Libido" theory had taken a back seat. Freud's ground-breaking earlier works on sexuality were still considered scorned and seedy. In ultraconservative Catholic Austria of the early 20th century, bringing up of sexuality as a scientific subject was considered highly provocative. Thus, he suspected rightly that the 
focus of psychoanalysis on sexuality along with the sexual, genital and orgasmic dysfunctions of its patients would have been a strong hindrance for the institutionalization of his science. Psychoanalysts therefore refused Wilhelm Reich's theories not based on scientific reasons but rather pursued a strategy similar to the communists.

\section{Reich in the United States-Burroughs and the Beats Discover Reich}

After leaving Vienna in the early 1930s, Reich continued his research on his holistic concepts in Scandinavia, investigating whether or not the orgasm is some sort of bioelectrical discharge that leads to relaxation. Coincidentally, while examining protozoa under a microscope, he discovered bright, glowing, blue vesicles "which, Reich asserted, represented transitional stages between nonliving and living substance" (Sharaf 1994, p. 217). He was convinced that these vesicles, which he later called "bions," were the basic prerequisite for the origin of life.

In early 1939 Reich emigrated from Norway to the United States, where he developed the idea that bions come to life by absorbing an omnipresent energy from the atmosphere that can be measured, as Reich claimed and which he called "orgone," an abbreviation for the words "orgasm" and "ozone." In what Myron Sharaf writes was the origins of the orgone theory, Reich said he could see two kinds of bions, the blue vesicles and smaller red ones shaped like lancets. He called the former PA-bions and the latter T-bacilli, the T standing for Tod, German for death. In his book The Cancer Biopathy, he wrote that he had found T-bacilli in rotting cancerous tissue obtained from a local hospital; when injected into mice they caused inflammation and cancer. He concluded that when orgone energy diminishes in cells through aging or injury, the cells undergo "biological degeneration" (Reich 1973a, p. 38). At some point the deadly T-bacilli start to form in the cells. Death from cancer, he believed, was caused by an overwhelming growth of the T-bacilli.

Orgone radiation, as Reich found out, can be concentrated in so called Orgone Accumulators, human-size boxes that Reich started building, which consisted of alternate layers of organic material such as wood or cotton and of inorganic material such as steel plates. The orgones are able to penetrate the layers and can be absorbed by organic material. The inorganic material absorbs the orgones as well but repels it quickly into the interior of the box were the radiation accumulates because it cannot escape through the steel plates as quickly as it entered. Now, if a laboratory mouse or a human being is inside of that box, it absorbs this accumulated orgone energy, which is able to weaken the T-bacilli in the organism. Reich was convinced that, as a result of this procedure and in combination with vegetotherapy, it would be possible to prevent, treat or even cure cancer. By his own account he succeeded in curing cancer in laboratory mice and, moreover, in his book The Cancer Biopathy, he also describes the case history of a cancer patient whose physicians declared that she would not survive more than two weeks. But with the combination of orgone therapy, vegetotherapy and psychoanalysis, the health of the patient increased significantly, and, according to Reich, the "X-rays clearly showed the healing process. They confirmed what I had frequently observed in the cancer experiments with mice, namely that orgone energy arrests the growth of the tumour and replaces it with a hematoma which, under favorable conditions, is reabsorbed and eliminated by connective tissue, or, if the tumor is in bones, by calcification." (Ibid., p. 170).

Reich's first publications in English, The Function of the Orgasm in 1942, Character Analysis, The Sexual Revolution, both 1945 and The Mass Psychology of Fascism in 1946, were carefully considered and "taken on board by New York intellectuals (and elsewhere)" (Miles 2014, p. 178). The Beats might have heard of Reich and his theories in conversation with others and by reading about it but it is doubtful if they had already read his books as well at that time. They do not appear in the book lists we can find whenever we read about Burroughs being labeled as a "mentor" of his younger friends Ginsberg and Kerouac and they are not mentioned let alone discussed in their letters until 1949.

In I Celebrate Myself, Bill Morgan writes that on New Year's Eve 1946 Allen Ginsberg sat in an orgone accumulator owned by a friend named Bridget O'Reilly (cf. Morgan 2006, p. 80). It is not known if this was his first contact with Reich. However, Morgan claims that at that time "Burroughs had 
been independently exploring Reichian theories for years and was a proponent of his orgone therapy" (Ibid., p. 83). But this is rather implausible, because in 1944/45 Burroughs was in psychoanalysis with Paul Federn-as mentioned above one of Reich's fiercest opponents in Vienna, who emigrated to the United States in 1938. As Reich explains in Reich Speaks of Freud, Federn viewed his explanation of the schizophrenic process as “distorted and even delusional” (Reich 1967, p. 12). Federn's approach was diametrically opposed to Reich's methods, which were directed towards the making conscious of the unconscious by all means, including to dissolve physical manifestations of emotions, that Reich in his Character Analysis called "body armor," by vegetotherapy and the use of the orgone accumulator. Besides, if Burroughs had been independently exploring Reichian theories for years, Reich would have played a role in Burroughs' amateurish attempts at analyzing Ginsberg and Kerouac at that time.

What is also known is that Ginsberg was on the lookout for a psychoanalyst in early 1947 and that in a letter to his younger friend, Burroughs suggested consulting one of the "Reichians." This means that Burroughs must have somehow become acquainted with Reich in 1946 or early 1947. Ginsberg then wrote a letter to Reich in which he asked to be treated by the analyst. John Tytell claims that Ginsberg "never actually sent" that letter (Tytell 1976, p. 84), which is what Johnston reiterates (Johnston 1984, p. 107). Yet in fact he did send the letter. It was replied to on March 17, 1947, by Reich's secretary and partner Ilse Ollendorff, recommending three analysts (Ginsberg 1934-1997, Box 1, Folder 57), of which Ginsberg chose Allen Cott, with whom the poet was in analysis for a while. The correspondence is archived in the Ginsberg Papers at Stanford University.

In June 1949, on his farm in Pharr, Texas, Burroughs' read Reich's latest volume The Cancer Biopathy, which had been published in 1948 - and he was enthusiastic about it. In his letter to Kerouac of 24 June 1949, he writes: "I tell you Jack, he is the only man in the analysis line who is on that beam. After reading the book I built an orgone accumulator and the gimmick really works. The man is not crazy, he is a fucking genius." (Burroughs 1993b, p. 51).

The sentence "After reading the book I built an orgone accumulator" is a bit confusing here, though. Because three months later, on September 26, Burroughs writes to Kerouac: "Jack, I wonder if you could do something for me? You know this gadget made by the Reichians called the accumulator? Could you find out from Al[len Ginsberg] or somebody what it looks like. I want especially to know its shape, where and if there is a window, how one gets into it"(Ibid., p. 53). Soon after this letter he had moved with his wife Joan Vollmer Burroughs from Texas to Mexico City. From there he writes to Kerouac on 2 November 1949: "I sure would appreciate it if you could find out where in Mexico City those accumulators are. I can not locate them" (Ibid., p. 56). In consideration of these requests it is interesting to learn what the first accumulator that Burroughs allegedly built in June 1949 actually looked like. It is also worthwhile mentioning that in The Cancer Biopathy, Reich explains the functionality of the orgone accumulator in great detail, detailing what material should be used for the layers and for what reason but indeed he does not mention anything about the shape of the device, its size, if there is a window, a door and so forth. In his book The Lost Years of William S. Burroughs: Beats in South Texas, Rob Johnson quotes Ted Marak, one of Burroughs' friends in Texas, who gives account of this early experiment. According to him, Burroughs' first orgone accumulator "was solid lead and open to the top. It bred the largest damn mosquitoes in South Texas." Johnson writes, "Ted told me, they put a mare that wouldn't foal into the orgone accumulator for treatment. Soon thereafter, she foaled. I told him I didn't realize it was big enough to accommodate a horse but he assured me it was. (When I told Pat Paris the story of the horse in the orgone accumulator, she asked me, sceptically, 'What part of the horse [fit in]?') I also asked Ted whether the orgone accumulator had the same effect on him that it did on Burroughs: In The Adding Machine, Burroughs writes that he built a portable orgone accumulator in 'an orange grove in Pharr, Texas and no hands achieved spontaneous orgasm age 37 old.' 'Shit,' Ted told me after hearing of this feat, 'back then, I had a hard-on all the time anyway" (Johnson 2006, pp. 34-35). In "My experience with Wilhelm Reich's Orgone Box," the essay in The Adding Machine from which Johnson is quoting, Burroughs recounts, "In a few days we had put up a wooden box about eight feet high and lined it with galvanized iron. Inside was an old icebox which you could get 
inside and pull on top so that another box of sheet steel descended over you. In this way the effect was presumably heightened by an accumulator inside an accumulator." (Burroughs 1993a, p. 164).

At that time another smear campaign against Reich was already in progress. After being villainized in Europe in the 1930s, Reich managed to establish himself in the United States as a serious psychiatrist and scientist whose publications were reviewed favorably in notable journals. But all this changed quite abruptly when Mildred Brady published her article "The Strange Case of Wilhelm Reich" in The New Republic in May 1947. In this tendentious text, she makes fun of the accumulator and mainly proclaims that the majority of all psychoanalysts are charlatans. This statement does not have to do anything with Reich but from there she returns to the orgonomist and points out that the "unsound practitioner" (Brady 2011, p. 7). Reich might be a danger to the general public. In May of 1947 Reich writes in his diary: "It's obvious this Mrs. Brady believes that I am the only man who could help her to achieve an orgasm, which she so desperately needs. The tragedy is: she is not aware of her need." (Reich 1999, p. 392).

Brady's views were passed on by many, unquestioned and obviously mostly without reading Reich's works. On the one hand this resulted in an incredibly distorted image of Reich as "mad scientist" with his "sex machines" in popular culture and the media in general, far beyond his death; with maybe one of the better known examples the machine called "Orgasmatron" in Woody Allen's Sleeper (1973) or as second example the evil Dr. Durand Durand in Roger Vadim's Barbarella (1968) who seems to be based on Reich and who places Barbarella (Jane Fonda) in his "Excessive Machine" so that she dies of pleasure but rather than killing her the machine burns out.

On the other hand, it resulted in a less funny and long lasting investigation by the US Food and Drug Administration (FDA). The methods of the FDA were highly dubious and by no means unaligned, let alone scientific. And "[p]sychoanalytic organizations, along with other groups, had encouraged the FDA to get rid of Reich's work" (Sharaf 1994, p. 402). To put it succinctly, at the end of this investigation Reich was accused of fraud, which led to an injunction that called for the destruction of the orgone accumulators (although, according to the court decision, they were ineffective as devices per se). The injunction also called for the destruction of all publications on orgonomy-which in fact included all of Reich's publications in the United States-and finally stipulated the imprisonment of Reich for two years. This wholesale destruction is considered by some to be one of the most blatant examples of censorship in U.S. history.

The Beats also certainly took note of this campaign. In the spring of 1950, Ginsberg wrote to Burroughs that he was "leery of Reich for no other reason than the general disrespect with which he is regarded" (Burroughs 1993b, p. 67), which Burroughs rebuked in his response of 1 May 1950: "Do you realize what you are saying here? You are saying that because a lot of people say something it must be right. What about your own feelings? If you had lived in Germany would you have been a Nazi? Hitler was voted in by a majority" (Ibid.). "Of course I built an orgone accumulator. 3 of them in fact. My experiments convinced me that Reich's orgones are real and demonstrable. Yet so-called Scientists go around saying he is insane and refuse even to investigate his findings"(Ibid., p. 70). So Burroughs was already fascinated by the orgone accumulator in 1949 but still wrote to Ginsberg in a letter from 24 December 1949 that he had not read the small book Listen, Little Man, a pamphlet published by Reich in 1948 and that "Reich's social and political theories and his polemics bore me" (Ibid, p. 57). By spring 1950 he must have changed his opinion, as one can read in his letter to Ginsberg.

The May 1 letter reveals that it was not only Reich's discovery of the orgone Burroughs was interested in and of which he was absolutely convinced. But he was also interested in how the public, media and officials, reacted on Reich's discovery. This is, of course, an example par excellence of how Burroughs was engaged with cases of alternative scientific approaches, which mainstream science often discredits for obscure reasons and often tries to prevent in an early phase. The aims for these courses of action might be manifold. Strategies of manipulation and control may play a role and machineries of power in both politics and economy that do not wish to improve the status quo for the 
sake of their profits. But, of course, if one entertains such suspicion, it will immediately get labeled as "conspiracy theory" and thus not taken seriously any further. As Burroughs puts it in The Job:

"New discoveries and products are suppressed because they threaten vested interests. The medical profession is suppressing Reich's orgone accumulator and his discoveries relative to the use and dangers of orgonic energy. They are suppressing the use of massive doses of Vitamin $\mathrm{E}$ for the prevention of the heart disease, the use of massive doses of Vitamin A for curing the common cold. (I have used this simple remedy for thirty years and it works. [ ... ] At the first soreness in the throat which presages the onslaught of a common cold you take 500,000 units of Vitamin A. Vitamin A alone. Not Vitamin C which is quite worthless for a cold. At one time I had thought to market this remedy but was told it could not be marketed by because the American Medical Association is opposed to self-medication. The AMA is opposed to self-medication if it works.) The medical profession is suppressing the use of apomorphine for the treatment of alcoholism and drug addiction and for the general regulation of disturbed metabolism. The medical profession has a vested interest in illness. They suppress any discovery that strikes at the roots of illness." (Burroughs 2008, pp. 60-61).

This sounds frighteningly plausible within the system of Burroughs' conspiracy theory. In reality, however, the authorization of medications and therapies is controlled by national agencies. These follow objectively verifiable results of scientific analyses with valid and wide-ranging data samples. Regarding Reich's approach to cancer therapy, no scientifically-sound tests have been conducted to this day. For this and other reasons, it is difficult to determine which of Reich's theories, discoveries and methods are really effective and which are not, especially if one is not a biologist, physician or physicist. Some of them sound logical, while some of them are diffuse. Reich's increasing paranoia at the end of his life is not very helpful either. For instance, in the 1950s he started talking about his connections to high government circles, which definitely did not exist; and whenever military aircrafts were flying above his laboratory, he thought that they are doing this to protect him from aliens and spaceships. Nevertheless, it is very odd that, until this day, no serious attempts were undertaken to repeat his experiments, so that the function of the orgone accumulator, his theories on curing cancer or his assumed theory of Deadly Orgone Radiation (DOR), which occurs by careless and excessive use of nuclear radiation, could be verified or falsified. In a PhD thesis from 2010, Günter Hebenstreit analyzed the electrophysiology of erogenous and non-erogenous skin zones in connection with the tension-charge-formula of Reich and already examined this formula in connection with phenomena such as a change of temperature inside an orgone accumulator in a diploma thesis in 1995. But Hebenstreit had no interest in making Reich's orgones visible through a microscope or any other method; he was only interested in the measurability of the effects of Reich's device-a task in which he succeeded (Hebenstreit 2010, p. 545). Not a single attempt has been made to (re)discover the blue and red particles Reich claims to have seen under his microscope in the 1930s. At least Hebenstreit states that the few "control experiments" on Reich's orgone theory were mostly without any serious scientific concept (Hebenstreit 1995, p. 4). The results of one of these experiments with a more serious scientific concept, undertaken by Rainer Gebauer and Stefan Müschenich at the University of Marburg, were published in a book entitled Der Reichsche Orgonakkumulator in 1987. According to the authors, significant psychophysical differences were measured between probands in an orgone accumulator and others sitting in a dummy. In particular, the probands' core body temperature-which usually does not change-increased significantly. Therefore, the authors seem to have verifiable evidence of the accumulator's effectiveness on human beings as postulated by Reich but state that the existence of the orgone still has to be proven (Gebauer and Müschenich 1987, p. 262).

\section{Reich and His Inventions, Discoveries and Theories in the Works of Burroughs}

In the "Chapter Twenty-Eight of the Original 'Junk' Manuscript," Burroughs provides an outline of Reich's findings and his theories and connects them with his own experiences as a Junky: "In junk 
sickness the junk-dependent cells die and are replaced. Cancer is a premature death process. The cancer patient shrinks. A sick junkie shrinks-I have lost up to fifteen pounds in three days. So I figured if the accumulator is therapy for cancer, it should be therapy for the after-effects of junk sickness" (Burroughs 2003, p. 135). He also describes the orgone accumulator and how he wanted to order such a device from Reich's Orgone Institute and sent them thirty dollars as a contribution to the Institute. "They sent back three forms to be filled out and signed. One was a we-are-not-responsible-for-anything affidavit. There was a pledge for me to sign that I would not let anyone else use my accumulator and would report to the Institute if I saw anyone building an accumulator and a questionnaire to be filled out by my physician what was wrong with me and why did I need an accumulator. I did not want to explain about orgones to some croaker who would take me for a lunatic. Besides, I did not like the way the Orgone people were coming on. Why say 'contributions' when you mean rent? And the pledge was ridiculous. So, I wrote them to send my money back and here are your forms" (Ibid.). After that Burroughs explains how he built an orgone accumulator on his own and what effects it had on him while being junk-sick. "After using the accumulator for several days my energy came back to normal. I began to eat and couldn't sleep more than eight hours. I was out of the post cure drag" (Ibid., pp. 135-36). In the published version of the book, only one paragraph refers to Reich and the Deadly Orgone Radiation (cf. ibid., pp. 88-89) but all other explicit references were deleted, because Burroughs, as he wrote in a letter to Ginsberg, did "not feel that the part about Reich [ ... ] belong there cluttering up the narrative." (Burroughs 1993b, p. 112).

The obscurity of Reich's theories and inventions and their denial by established science leads to the effect that Burroughs, in his œuvre, can use, amongst others, Reich's theories, which incidentally in the meantime have been categorized as "parascience," to establish his well-known cosmos of (so called) conspiracies, in which such theories get suppressed by governments, industries and higher forces, so they can absorb them for themselves to manipulate and control societies. Or guerrilla combatants and other underground fighters who use Deadly Orgone Radiation against their enemies. Orgone energy and accumulators appear as a matter of course in Burroughs' writings. The "exotic" concepts and devices of a marginalized and attacked single combatant gain the status of firmly established scientific and technical achievements. Evaluation criteria of western society as we know it only play a subordinate role in his fictional worlds.

We find "sellers of orgone tanks and relaxing machines" in the Meet Café of Naked Lunch (Burroughs 2005, p. 91), friendly advices such as "when those hot licks play over your balls and prick and dart up your ass like an invisible blue blow torch of orgones, in the words of T. J. Watson, Think" (ibid., p. 37) and the "Wise Man [ ... ] converting [ ... ] live orgones into dead bullshit" (Ibid., p. 97). While in the deleted chapter of Junky Burroughs describes that sitting in the orgone accumulator he "noticed a special silence that you sometimes feel in deep woods, sometimes on a city street, a hum that is more a rhythmic vibration than a sound" (Burroughs 2003, p. 135), in Naked Lunch this sentence gets transformed into "The vibrating soundless hum of deep forest and orgone accumulators, the sudden silence of the cities when the junky cops and even The Commuter buzzes clogged lines of cholesterol for contact" (Burroughs 2005, p. 174). A paranoid hustler claims that "they wanta suck my orgones" (ibid., p. 105) and in the "Atrophied Preface" entitled "Wouldn't You?," "Orgone balked at the post ... Christ bled ... Time ran out ..." (ibid., p. 187).

Due to the nature of the cut-up method, the reason for appearances of Reich and his orgones in the Nova Trilogy are difficult to deduce, since narration in conventional terms does not exist in these works. Instead keywords such as "Reich," "orgone" or "DOR" contribute to the atmosphere the text creates. But this is not only a matter of coincidence due to the cut-up, as one could assume. A key feature of the 1961 Soft Machine "is its unique structural organization into color Units (Red, Green, Blue, White), only traces of which would remain in later editions," as Oliver Harris explains in his introduction to the restored version of the book. "The structure came from Rimbaud's poem 'Voyelles' (minus black) and also reflected Burroughs' intense preoccupation with color stimulated by other sources, including the drugs yagé and apomorphine and the orgones of Wilhelm Reich (all 
associated with blue)" (Harris 2014, p. xxxiv). Using material for the cut-up texts in which Reich or orgones are mentioned results in paragraphs such as this one: "You will die there a screwdriver through the head. The thought like looking at me over steak and explain it all like that stay right here. She was also a Reichian Analyst. Disappear more or less remain in acceptable form to you the face" (Burroughs 2014a, p. 68). After mentioning the "blue mountains" in Nova Express, which also occur numerous times in Soft Machine, Burroughs explains in a footnote: "Since junk is image the effects of junk can easily be produced and concentrated in a sound and image track-Like this: Take a sick junky-Throw blue light on his so-called face or dye it blue or dye the junk blue it don't make no difference and now give him a shot and photograph the blue miracle as life pours back into that walking corpse-That will give you the image track of junk-Now project the blue change onto your own face if you want The Big Fix. [ ... ] Doctor Wilhelm Reich has isolated and concentrated a unit that he calls 'the orgone'-Orgones, according to W. Reich, are the units of life-They have been photographed and the color is blue-So junk sops up the orgones and that's why they need all these young junkies-They have more orgones and give higher yield of the blue concentrate on which Martin and his boys can nod out a thousand years-Martin is stealing your orgones-You going to stand still for this shit?" (Burroughs 2013, p. 7) In another section of Nova Express, "naked cadets entered a warehouse of metal-lined cubicles [ ... ]--Blue light played over their bodies" (ibid., pp. 166-67), after which another footnote about Reich and orgones follows.

The exact same footnote is to be found as well in The Ticket That Explodes, where people applying for entry to the "sex area of the amusement park [ ... ] must submit to naked photographic processing for ten days during which the applicant is photographed in all stages of erection, orgasm, defecation, urinating, eating-The pictures are cut down the divide line of the body and fitted to other pictures of prospective partners-The photos vibrated and welded together in orgone accumulators" (Burroughs 2014b, pp. 77-78). In the same book Burroughs also writes of "orgone accumulators flickering blue over swimming tanks where naked youths bathed in blue" (ibid., p. 71); "Bradley moved into a maze of orgone accumulators-circular rooms lined with magnetic iron-He entered the maze with three other boys-In the first chamber they found iron frames on which they stretched their bodies in different positions of exposure-A vibrating silence hummed through the magnetized air-Tingling blue light touched his rectum and genitals playing along the divide line left a taste of metal in the mouth-Smaller accumulators with hose attachments turned directly on erogenous zones the message of orgasm received and transmitted" (ibid., p. 86). The orgone leitmotif soon undergoes a denseness in combination with the subject of "Orgasm death": "Wheee' the sex act soften you up to buy death in orgasm of copy planet-Other side throwing the orgone accumulators-take over all sexual apparatus-smell of moldy jockstraps and chlorine ejaculating- [ ... ] feedback-noise of accumulators-You see the caustic layers of organic material? [ ... ] pass along the orgone in throat gristle alternating body- $[. .$.$] Orgones through iron repetition setting off word tape response in the$ other nervous system - image of a separate being touched lungs penis and electric body hairs-now passes along orgone in throat gristle alternating sex words to color" (ibid., 87-88) It seems that Reich's concept of the orgones as a life energy that flows freely in the body of the genital character and enables orgasmic potency gets abused by antagonists who "monopolize life" (Johnston 1984, p. 116) to control people as it is also undertaken with the drug business as "anti-life force."

For Reich, neuroses and other psychic disorders as well as physical illnesses such as cancer are caused by the prohibition of natural sexual gratification, for instance oppression of (childhood) sexuality in the name of false morality through religions and/or patriarchal systems or "disturbance, indeed the impossibility, of regulated, physiologically adequate sexual gratification, even under the best inner conditions" (Reich 1973b, p. 204), due to the housing problem and exploitation of labor caused by capitalism and industrialization, as a result of which population in the cities exploded. According to Reich, in 1927 "more than 80 percent of the population of Vienna lived four and more in one room." Also, "A Person harassed by basic material needs cannot enjoy any kind of pleasure and easily becomes a sexual psychopath" (ibid.). These and many other factors result in what Reich calls 
the "emotional plague." To the majority the power structures are invisible, which makes it easy for those in power to misuse their authority, to increase their dominance through manipulation and, at its core, sexual repression. The treatment of Carl Peterson by Doctor Benway in the "Examination" chapter of Naked Lunch (Burroughs 2005, pp. 155-65), after he has been ordered to the "Ministry of Mental Hygiene and Prophylaxis" for inexplicable reasons to him, is one example of how Burroughs lays bare such mechanisms and procedures. But instead of "merely demonstrating the effects of this repression, Burroughs shows us the tool whereby it is achieved," as Johnston explains. "If sexuality is the basic, natural expression of life, power over sexuality equals power over life" (Johnston 1984, p. 117). Sexual repression naturally leads to sexual desire and abnormal urge-just as a junk withdrawal for an addict leads to the need to score. The hunger for fulfilment can be misused to monetize sexuality by prostitution and pornography. Moreover, as Reich writes in The Function of the Orgasm, the social framework of "modern" societies, with their origins in a (patriarchal) system that is thousands of years old, leads to "sexual murder, criminal abortions, the sexual agony of adolescents, the killing of all vital impulses in children, perversions en masse, pornography and the vice squad that goes with it, exploitation of the human longing for love by a cheap and prurient consumer industry and commercial advertising, millions of illnesses of a psychic and somatic nature, loneliness and psychic deformity everywhere" (Reich 1973b, p. 228) and finally to a fascist deluge (or similar ideologies), as Reich explained in detail in his book The Mass Psychology of Fascism as well as in other publications. Burroughs draws the dystopian picture of a later, maybe final stage of this development, of a society gone wrong, his work "may usefully be seen as a fictional dramatization of Wilhelm Reich's definitions of 'emotional plague'"' (Mottram 1977, p. 119), as Eric Mottram writes in The Algebra of Need, with the longing for "orgasm death" - the opposite of what orgiastic potency intrinsically stands for-as one of its disturbing symptoms.

Burroughs' view of society-“its organization, repressions and illnesses-is definitely Reichian," as Johnston states, "indeed, Burroughs' entire vision emphasizes a continuity between microcosmos and macrocosmos which strongly resembles Reich's orgonotic functionalism" (Johnston 1984, p. 119). After returning to a more conventional form of narration in his Cities of the Red Night Trilogy (and after suggesting to consult Reich's Collected Works for constructing "teleport and exteriorization equipment" in Port of Saints (Burroughs 1980, p. 45)), Burroughs does not cease to include Reich's theories in his works. Au contraire, one key subject in The Western Lands is Deadly Orgone Radiation (DOR). In Cities of the Red Night, Yen Lee, somewhere in the Far East, encounters the smell of death and suspects that a secret laboratory in a monastery "contain[s] a sophisticated DOR installation" (Burroughs 1981, p. 15). Scientists in a boardroom discuss the origins of Virus B-23 and Doctor Peterson asks Doctor Pierson, if it has occurred to him that the wondrous "radiation emanating from the red light $[\ldots]$ might be similar to Reich's DOR or Deadly Orgone Radiation, which is produced by placing radioactive material in an organic container lined with iron?" Pierson's subsequent outburst: "Preposterous! Reich was a charlatan! A lunatic!" (Ibid., p. 23). The DNA police force that is responsible for biologic inspection and quarantine measures is "armed with the most sophisticated weapons: Infra-Sound and DOR guns, fear probes, death guns that can be adjusted to kill, stun or disperse and devices shooting tiny pellets of nerve gas and toxins." (Ibid., p. 277).

A sequence in The Western Lands reminds one of Ted Marak's anecdote about the mare in Burroughs' first orgone accumulator almost four decades earlier. Here the outlaw Joe Laz, also known as Joe the Dead, "specializes in evolutionary biology" (Burroughs 1987, p. 32) and "set out to produce a fertile mule. He exposed horse and donkey sperm to orgone radiation in a magnetized pyramid and inseminated the mare—-didn't hack it. So Laz went further: he rigged a magnetized stall and bombarded the copulating animals with DOR—Deadly Orgone Radiation. He sewed himself into a goat skin and whipped his beasts to wild Pan music - any woman hit by the Goat God's whip will conceive-and finally he created a fertile mule" (Ibid., p. 33). But Joe shares Wilhelm Reich's fate and "Skeptics pronounced Joe Laz's mule the most colossal hoax since the Piltdown Man" (ibid.). He is meditating about interspecies transplants: "Say, the brain of a chimp in a man's body. Unhampered by 
the crippling emotional blocks so carefully installed in humans by interested parties, the chimp might prove to be a super-genius; that is to say, he might realize a relatively larger segment of the human potential" (Ibid., p. 39). And he goes so far to resume Reich's work, trying to treat cancer by a device based on "Reich's Orgone Accumulator, a construction of organic material lined with iron or steel wool. Joe has added a number of alterations, notably magnetized iron, which vastly potentiate the action" (Ibid., p. 60). Short thereafter Burroughs takes the opportunity to express his thoughts about the case of Reich: "So Joe has left a cloud of ink behind him like a retreating squid in the form of his Orgone Cancer Cure, like a cure for death itself, so closely is cancer linked with death. Exaltation sweeps through cancer wards and cancer-ridden outpatients and with regained vitality comes anger: Why have doctors concealed this cure? Why did the FDA burn Reich's books and suppress his findings without a trial? (One judge refused to listen to any testimonials.) The medical profession has suffered a horrific loss of prestige and credibility, compounded by frantic efforts to discredit the cure in the face of mounting evidence of its effectiveness" (Ibid., p. 63). Close to the end of the book that was published in 1987, two years before the official end of the Cold War, "Russian missiles hit Washington D.C. [ ... ] Geiger counters click to countdown. Decaying lead spells out the last syllables of recorded time," and what follows are the same short sentences that already appear in the "Atrophied Preface" of Naked Lunch: "Orgone balked at the post. Christ bled. Time ran out." (Ibid., p. 222).

There are plenty of other examples where Burroughs incorporates Reich's ideas in his œuvre, for instance in the Blade Runner screenplay and especially in his non-fiction writings such as The Electronic Revolution or The Job. In the latter a lengthy section of the chapter "Prisoners of the earth come out" is dedicated to the discussion of DOR. In the above-mentioned "My Experiences with Wilhelm Reich's Orgone Box" in The Adding Machine, Burroughs does not only describe his first orgone accumulator but also shares his thoughts about the persecution of Reich and makes clear that Kerouac's account in On the Road is not based on facts. "Kerouac [ ... ] never set foot on the South Texas farm. [ ... ] Kerouac even went so far as to write that 'Old Bull thought his orgone accumulator would be improved if the wood he used was as organic as possible, so he tied bushy bayou leaves and twigs to his mystical outhouse.' Like so much of Jack's writing, this makes a good story but is actually pure fiction. When he visited me I was living in Algiers, across the river from New Orleans, in a little house laid out like a railroad flat and raised up on the marshy lot by concrete blocks. In Algiers I had practically no front yard at all and was far too busy with a habit to build an accumulator. Neal Cassady did visit me at the South Texas farm but never used the orgone box. Since Kerouac presumably got the story of my first accumulator from Cassady, whose tendency to exaggerate rivalled Jack's, it's a wonder they didn't have me throwing orgies in the accumulator for the amusement of the wetbacks." (Burroughs 1993a, p. 164).

\section{Reich in Interviews Given by Burroughs}

Also, in interviews throughout the years Burroughs does not get tired of explaining that Reich's "non-conventional theories frequently touch on something that's going on that Harvard and M.I.T. can't explain" (Lotringer 2001, p. 79). Nevertheless he occasionally changed his opinions and was not always convinced that Reich was really a "fucking genius," which is well documented thanks to interview collections such as Sylvère Lotringer's Burroughs Live. In the 1965 interview with Conrad Knickerbocker, Burroughs expresses his conviction that sex "has been degraded for control purposes" and used as a "biological weapon": "This whole puritanism. How are we ever going to find out anything about sex scientifically when a priori the subject cannot even be investigated? It can't even be thought about or written about. That was one of the interesting things about Reich. He was one of the few people who ever tried to investigate sex-sexual phenomena, from a scientific point of view. There's this prurience and this fear of sex. We know nothing about sex. What is it? Why is it pleasurable? What is pleasure? Relief from tension? Well, possibly." (Ibid., p. 81).

Three years later he describes the concept of DOR in the New York underground newspaper Rat in the context of "Supressed Discoveries" (ibid., pp. 113-15). In 1973 (ibid., p. 828; according to Eric C. Shoaf's Burroughs Bibliography on the website RealityStudio it was 1979) he contributed 
an essay about "Sexual Conditioning" for The Gay Liberation Book (reprinted in The Adding Machine) and disagrees with Reich in an accompanying interview with Gay Sunshine, printed in 1974, that a patriarchal society is "anti-sexual in general. I say the opposite-all matriarchal societies are anti-sexual in general and specifically anti-homosexual. It's to the advantage of women" (Ibid., p. 198). Burroughs, for his misogynistic argument, ignores female homosexuality completely here and over-simplifies Reich's theory which he had approved to corroborate other beliefs. Oddly enough he identifies the United States as well as England as matriarchal societies and claims that the "only patriarchal society that I know exists today is the Arab and of course, they're tolerant" towards homosexuality (Ibid.). It seems that with regard to this subject Burroughs reflexively had to disagree with Reich, who was not explicitly anti-homosexual like many of his contemporary colleagues but considered it as "abnormal" and as compensation coming out of unconscious fear of - in case of gay men-the woman or other phobias and fixations, which are basically a result of patriarchal systems.

The following example demonstrates that Reich draws a more complex picture of the dichotomy between patriarchal societies and matriarchies. In The Function of the Orgasm, he refers to the matriarchal Trobriander society which (in the 1930s) "was ignorant of any sexual perversions, functional mental illnesses, psychoneuroses, sexual murder; they had no word for theft. In their society, homosexuality and masturbation were looked upon as incomplete and unnatural means of sexual gratification, as a proof that the capacity of normal gratification is hampered. [... ] Hence, the Trobriander is spontaneously clean, orderly, naturally social, intelligent and industrious. Non-compulsive, voluntary monogamous marriage, which can be dissolved at any time without difficulties, prevails as the social form of sexual life. There is no promiscuity. A few miles from the Trobriand Islands, on the Amphlett Islands, there lived a tribe that has a patriarchal, authoritarian family arrangement. All the characteristics of the European neurotics (distrust, anxiety, neuroses, suicides, perversions, etc.) were already evident in the natives of this island. Our science, which is so steeped in sexual negation, has thus far succeeded in nullifying the importance of decisive facts by placing side by side and equating what is important and what is unimportant, what is commonplace and what is extraordinary" (Reich 1973b, pp. 230-31). Although Burroughs misrepresents these notions and abridges the topic considerably, in the interview for Gay Sunshine he ultimately admits that "there's no question that the Orgone Accumulator, even in its present state, does enhance sexuality. [ ... ] Undoubtedly something does happen to you. You feel healthier and sexier from using them regularly." (Lotringer 2001, pp. 200-1).

In several interviews from that time, he expresses his own thoughts for enhancing the device, for instance, to potentiate its effect "by using magnetic iron" (ibid., p. 200) or by "making an Orgone Box in the shape of a pyramid" (ibid., p. 212). In a conversation with David Bowie in 1974 he shares his thoughts of setting up an "Institute of Advanced Studies somewhere in Scotland [ ... ] to extend awareness and alter consciousness in the direction of greater range, flexibility and effectiveness at a time when traditional disciplines have failed to come up with viable solutions." Besides "yoga-style meditation and exercises, communication, sound, light and film experiments with sensory deprivation chambers, pyramids, psychotronic generators [... ], experiments with infra-sound, experiments with dream and sleep," and so forth, orgone accumulators should also be used (Ibid., p. 235). Burroughs' own theoretical developments of utilizing orgone energy by applying a certain architecture (accumulators the shape of a pyramid) and magnetism connect Reich's concepts to secret doctrines (those of the ancient Egypt, Mesmerism, etc.) that are also considered parasciences. As a result, orgone theory becomes the component of an exceptional irrational cosmos that at the same time examines contemporary social and political phenomena in a supernatural way.

In the same year, 1974, Burroughs says that in the development of his social theories, "Reich was not that important to me [ ... ] I never paid much attention to his social theories. The Orgone Accumulator, however, was an important discovery; it's quite a useful instrument" (Ibid., p. 265). Hereupon he proclaims that "Psychoanalysis is a complete and utter waste of time and money as far as I am concerned. I've very rarely seen anyone cured; they think they are, they say they are. It goes on for years and nothing substantial happens" (Ibid., p. 266). Soon thereafter, in an interview in 
Boulder, Burroughs stated that "the importance of Reich cannot be overestimated. Not so much for his experiments with sex. I was thinking rather of Orgone Accumulators as possible cancer cure. And I'm convinced that experimentation could lead to something. But the medical establishment won't even listen or try to do anything. It's harmless, why not try it? [ . . ] It's a big business. It's also becoming pandemic - one in five will die of cancer. Also remember that cancer is a new disease. If you go back 200 to 300 years, you'll find no references to cancer. Of course, medical diagnosis was very imprecise but if there had been as many cancer cases as there are now, you would have found it described ... It seems that cancer came in with the industrial revolution and that any lead is worth following ..." (Ibid., p. 326).

A conversation between Burroughs, Ginsberg, Carl Solomon and Maurice Girodias in 1975 provides an account that Burroughs not always understood Reich's thinking entirely. Asked by Ginsberg what Reich's thesis in The Sexual Revolution was, he answers that "the more sexual oppression, the more rooms people need. That way, you can sell them and get them living in larger apartments" (ibid., p. 340), which doesn't have anything to do with the housing problem of the working class that causes psychic and physic illnesses due to suppressed sexuality, which is what Reich was actually referring to. Finally, in an interview in 1978 in Paris, Burroughs again expresses his opinion that the entire approach of psychoanalysis "is, in part, mystical: its 'superego' has no basis in the nervous system. Every psychic event is a chemical event." Asked how his analysis developed, he repeats, "I feel I wasted my time. Very few people who have gone to see psychoanalysts have obtained interesting results." The surprising question if Burroughs has read Freud leads in the end to a surprising answer: "No, not at all" (Ibid., p. 411), which is quite remarkable for a writer like Burroughs who was treated by the Freudian analyst Paul Federn in the 1940s and expressed his ressentiments against Freud's theories decades later in the essay "On Freud and the Unconscious."

\section{Conclusions}

The fact remains that Wilhelm Reich and his theories had a major influence on Burroughs' writings, from the beginning onwards and into his late works and were of similar if not even more important significance than other neglected theorists such as Alfred Korzybski or L. Ron Hubbard. He was definitely more attracted to Reich's approach of psychoanalysis than to Freud's, because Reich was more interested in the connection between the psyche and soma as well as the societal mechanisms and their effect on the psyche, including technical devices such as the orgone accumulator which Burroughs could integrate in his technological inventory. Moreover, the biography of Reich fascinated Burroughs throughout his life, even if he states in an interview with his biographer Ted Morgan that he "didn't feel so much sympathy for him as a persecuted figure ... I thought he was a goddamn fool ... he didn't have any sense ... he snapped ... [ . . . ] If Reich had kept his cool he would never have gone to jail ... " (Morgan 1983-1988 Papers, Box 10, Folder 11). Also his "official" denial of the interest in Reich's social theories seems exaggerated. In The Mass Psychology of Fascism, Reich at length describes the patriarchal structures which lead via "family values" and the "repression of intimacy and sexual relations" (Birmingham 2011) to the extreme right-wing, authoritarian system that led to World War 2 and the Holocaust. As Jed Birmingham also stated, Burroughs "would describe love as a virus and express Reichian views on the family" (ibid.), for instance in The Job.

The dystopian universes of Burroughs' Naked Lunch and the Nova Trilogy can be considered as worst-case scenarios spreading an "emotional plague" as described by Reich or the worst development imaginable as outlined in Reich's The Mass Psychology of Fascism. Orgones, accumulators, D.O.R. et al. unfold a surreal life of their own in Burroughs' fiction, detached from the theoretical background most of Burroughs' readers are not familiar with and become features of an idiosyncratic science fiction that reflects on contemporary tendencies in society, media and politics-as all sophisticated literature in this genre does. One could also explicitly refer to Reich's materialistic approach, especially his fundamental sociological and somatic understanding and his dialectic conception of psychic and social processes (as outlined in The Mass Psychology of Fascism). Such a dialectic approach definitely 
corresponds with Burroughs' idea of the relationship between body and mind, which he expresses in motifs of connecting the physical body and its psychic apparatus with machines. Due to space limitations, an analysis of such connections has to be undertaken in a future study.

It is worth mentioning that Reich's concept of orgone energy is basically a positive phenomenon associated with individual freedom and liberation, which Burroughs first is eager to distribute, whereas he demonstrates his pessimism in later works in which a central motif is the utilization of the negative D.O.R. by diverse powers for control and suppression. Though it remains unclear which of Reich's publications besides The Cancer Biopathy Burroughs factually had read, the numerous extant passages in Burroughs' works about Reichian theories and thinking, some of which have been outlined in this article, should provide ample evidence that whenever Burroughs downplayed the esteem he had for Reich, it was mostly inaccurate.

Funding: This research was funded by the Austrian Science Fund, project no. P 29348

Conflicts of Interest: The author declares no conflict of interest.

\section{References}

Birmingham, Jed. 2011. “Minutes to Go and Mad Men." Reality Studio. Available online: https://realitystudio.org/ bibliographic-bunker/minutes-to-go-and-mad-men/ (accessed on 4 January 2019).

Brady, Milford. 2011. The Strange Case of Wilhelm Reich. The New Republic. May 26, 1947. Available online: https://pdfs.semanticscholar.org/f521/f8bd472947ca783e34d5576df651b83d3e3b.pdf (accessed on 4 January 2019).

Burroughs, William S. 1980. Port of Saints. Berkeley: Blue Wind.

Burroughs, William S. 1981. Cities of the Red Night. New York: Picador.

Burroughs, William S. 1987. The Western Lands. New York: Viking.

Burroughs, Willam S. 1993a. The Adding Machine. Selected Essays. New York: Arcade.

Burroughs, William S. 1993b. The Letters of William S. Burroughs 1945-1959. Edited and Introduced by Oliver Harris. New York: Penguin.

Burroughs, William S. 2003. Junky. The Definitive Text of "Junk". Edited and Introduced by Oliver Harris. New York: Penguin.

Burroughs, William S. 2005. Naked Lunch. The Restored Text. Edited by James Grauerholz and Barry Miles. Introduced by James Graham Ballard. London: Harper Perennial.

Burroughs, William S. 2008. The Job. New York: Penguin.

Burroughs, William S. 2013. Nova Express. The Restored Text. Edited and Introduced by Oliver Harris. New York: Grove.

Burroughs, William S. 2014a. The Soft Machine. The Restored Text. Edited and Introduced by Oliver Harris. New York: Grove.

Burroughs, William S. 2014b. The Ticket That Exploded. The Restored Text. Edited and Introduced by Oliver Harris. New York: Grove.

Gebauer, Rainer, and Stefan Müschenich. 1987. Der Reichsche Orgonakkumulator. Naturwissenschaftliche Diskussion. Praktische Anwendung. Experimentelle Untersuchung. Frankfurt am Main: Nexus.

Ginsberg, Allen. 1934-1997. Allen Ginsberg Papers 1934-1997. Stanford: Department of Special Collections, Sign. No. M0733, Stanford University.

Harris, Oliver. 2014. Introduction. In The Soft Machine. The Restored Text. Edited by William S. Burroughs. Introduced by Oliver Harris. New York: Grove.

Hebenstreit, Günter. 1995. Der Orgonakkumulator nach Wilhelm Reich: Eine experimentelle Untersuchung zur Spannungs-Ladungs-Formel. Diploma [Master's] thesis, University of Vienna, Vienna, Austria.

Hebenstreit, Günter. 2010. Die Elektrophysiologie erogener und nicht-erogener Hautzonen in Verbindung mit der Spannungs-Ladungs-Formel Wilhelm Reichs: Eine experimentelle Untersuchung. Ph.D. thesis, University of Vienna, Vienna, Austria.

Johnson, Rob. 2006. The Lost Years of William S. Burroughs. Beats in South Texas. College Station: Texas A\&M University Press.

Johnston, Allan. 1984. The Burroughs Biopathy: William S. Burroughs' Junky and Naked Lunch and Reichian Theory. Review of Contemporary Fiction 4: 107-20.

Kerouac, Jack. 2000. On the Road. Introduction Ann Charters. New York: Penguin. First published 1957. 
Kerouac, Jack. 2007. On the Road. The Original Scroll. New York: Viking.

Lotringer, Sylvère, ed. 2001. Burroughs Live. The Collected Interviews of William S. Burroughs 1960-1997. Los Angeles: Semiotext(e).

Miles, Barry. 2014. Call Me Burroughs. A Life. New York: Twelve.

Morgan, Ted. 1983-1988. Ted Morgan Papers 1983-1988. Rare Books and Manuscripts Collection, Sign. MS SC MOR, AZ. Tempe: Arizona State University Library.

Morgan, Bill. 2006. I Celebrate Myself. The Somewhat Private Life of Allen Ginsberg. New York: Penguin.

Mottram, Eric. 1977. William Burroughs. The Algebra of Need. London: Marion Boyars.

Reich, Wilhelm. 1967. Reich Speaks of Freud. Wilhelm Reich Discusses His Work and His Relationship with Sigmund Freud. Edited by Mary Higgins and Chester M. Raphael. Translated by Therese Pol. New York: Farrar, Strauss and Giroux.

Reich, Wilhelm. 1973a. The Cancer Biopathy. Volume II of The Discovery of the Orgone. Translated by Andrew White, Mary Higgins, and Chester M. Raphael. New York: Farrar, Strauss and Giroux.

Reich, Wilhelm. 1973b. The Function of the Orgasm. Sex-Economic Problems of Biological Energy. Translated by Vincent R. Carfagno. New York: Farrar, Strauss and Giroux.

Reich, Wilhelm. 1999. American Odyssey. Letters and Journals 1940-1947. Edited by Mary Boyd Higgins. Translated by Derek, Inge Jordan, and Philip Schmitz. New York: Farrar, Strauss and Giroux.

Sharaf, Myron. 1994. Fury on Earth. A Biography of Wilhelm Reich. Cambridge: Da Capo.

Stevens, Michael. 2009. The Road to Interzone: Reading William. S. Burroughs Reading; Archer City: Suicide Press. Available online: https://rspull-supervert.netdna-ssl.com/images/covers_other/road_to_interzone/michaelstevens.the-road-to-interzone.pdf (accessed on 4 January 2019).

Tytell, John. 1976. Naked Angels. Kerouac, Ginsberg, Burroughs. Chicago: Ivan R. Dee.

(C) 2019 by the author. Licensee MDPI, Basel, Switzerland. This article is an open access article distributed under the terms and conditions of the Creative Commons Attribution (CC BY) license (http://creativecommons.org/licenses/by/4.0/). 